HISTORICAL/BIOGRAPHICAL ESSAY

\title{
Wellman's 1906 polar expedition: the subject of numerous newspaper stories and one obscure film
}

\author{
Jan Anders Diesen \& Neil Fulton \\ Faculty of Television Production and Film Studies, Lillehammer University College, Lillehammer, Norway
}

\author{
Keywords \\ Film history; polar expedition; travelogue; \\ Wellman; Svalbard.

\section{Correspondence} \\ Jan Anders Diesen, Faculty of Television \\ Production and Film Studies, Lillehammer \\ University College, NO-2626 Lillehammer, \\ Norway. Email: jan-anders.diesen@hil.no
}

\begin{abstract}
The following contribution, by film researchers Jan Anders Diesen and Neil Fulton, is the second piece about Walter Wellman in this issue. Whereas Capelotti et al. (this issue) focus on technical aspects of Wellman's aborted bid for the North Pole in 1906, Diesen and Fulton look at the media hype surrounding the event. They also describe an obscure short film that includes scenes of Wellman in Svalbard in 1906. Although Wellman's credentials as a polar explorer can be questioned, there is no doubt that he excelled at publicizing his ambitious schemes to the world.
\end{abstract}

-The editor

doi:10.1111/j.1751-8369.2007.00007.x

Preparing a lecture on British travelogues from Norway, to be given at The British Silent Cinema Festival in Nottingham in March 2006, we were looking for films made by British film-makers in Norway in the early years of the last century. One that turned up in the records of the British Film Institute included Bergen harbour in its description. When we received a copy of the film from the National Film and Television Archive its full title was revealed as 1906 The Wellman Polar Expedition-set out from Bergen to Spitzbergen (Charles Urban, $470 \mathrm{ft}$ ). It was obvious that this was no ordinary travelogue from Norway. The scenes in the film were so much more than the 100-year-old footage of Bergen harbour that we'd hoped for. We saw scenes from the Norwegian coast, tourist outings and hunting expeditions, and a lot of footage from Spitsbergen, showing a range of activities. The film was set apart from others we had seen from the hands of people like Robert Paul or Cecil Hepworth. This film was clearly worth a study all of its own. This article aims to unravel the mystery of this film and throw some light on its subject matter.

In the summer of 1906, two national events dominated the front pages of the Norwegian newspapers, namely the coronation of King Haakon and Queen Maud in Trondheim and the passing away of Henrik Ibsen. It seems that Wellman's polar expedition from Spitsbergen was a close contender for third place. These days, the American would-be polar explorer Walter Wellman is quite understandably a forgotten figure. His five attempts to reach the North Pole can only be described as disastrous, and there are only a few lines devoted to him in Drivenes \& Jølle's (2004) recently published comprehensive history of Norwegian polar exploration. Ill prepared, Wellman attempted several methods of reaching the North Pole: by foot (1894), by dogsled (1898-99) and with airships and motorized sledges (1906-09). It was the first airship attempt that was the big media event in 1906, and not only in Norway.

The polar expedition was a media event long before Wellman left for the northern reaches with his airship. His plans were first announced in the American newspapers; European publications weren't far behind. In Norway, Wellman was already front page material when he moved north to establish his base on Danskøya (Danes Island) in Svalbard. Articles in the Norwegian newspapers based in the towns closest to Wellman's activities make it possible to follow his route out from Bergen [Bergens Tidende (The Bergen Times)], along the northern Norwegian coast [Tromsøposten (The Tromsø Post) and Nordkapp] and further north to Spitsbergen.

Short announcements in Bergens Tidende described Wellman's progress from his arrival in Norwegian waters at Arendal (on 19 June 1906) to his arrivals in Trondheim (26 June) and Tromsø (30 June) (Fig. 1). On 6 July, the expedition left Tromsø and Wellman was "determined to make an attempt as soon as this autumn, even if he were forced to wait until December for favourable winds" (this and text from other newspaper articles has been translated by the authors). On 20 July, the front page of Bergens Tidende featured an article entitled "Who is Walter 


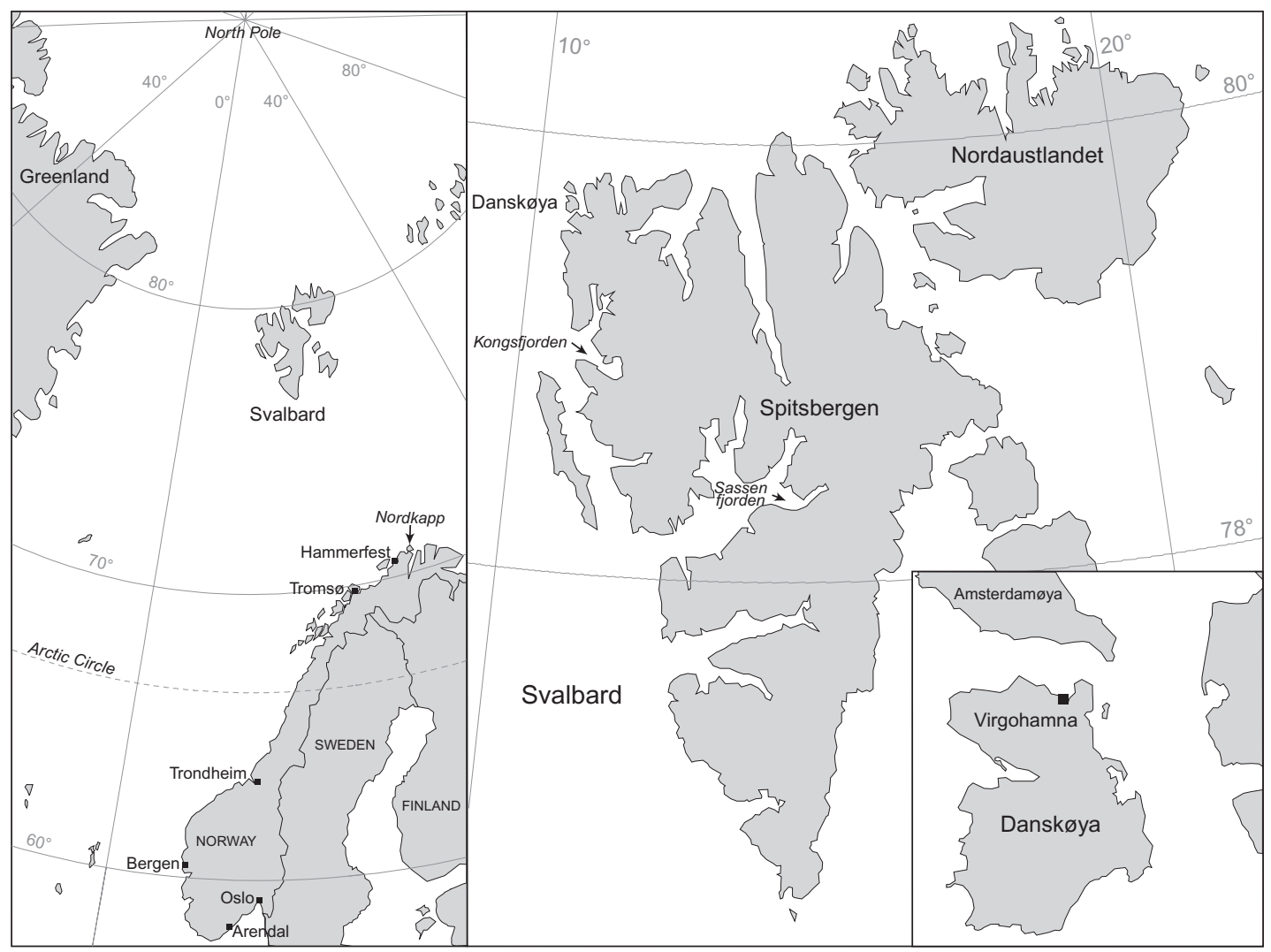

Figure 1 Sketchmaps of Scandinavia, Svalbard and Danskøya.

Wellman?" The newspaper had found it warranted to print a more rounded presentation of the man:

Of the new leader of the journey to the North Pole, Walter Wellman, Andrée's successor, we know little more than that he is a correspondent for the Chicago newspaper, The Record-Herald. A few personal notes on this enterprising journalist should therefore be of some interest to the reader. Wellman was born 47 years ago in the deep forests of Michigan. At the age of 12, he was an assistant at a trading post, where the majority of the customers were North American Indians. A year later, he became a printer's apprentice and founded his own newspaper at the age of 14. After moving to Ohio he established several more newspapers, which he subsequently sold. Since 1884 he has been The RecordHerald's correspondent and as such commands a princely wage. On assignment from the newspaper, he searched for and was successful in locating the exact spot at which Columbus set foot in the New World. (Bergens Tidende 20 July 1906)

As it was a relatively large newspaper, Bergens Tidende received telegrams from major bureaus like Reuters, and on 18 July it announced that Wellman, hopes to establish a wireless telegraph connection with Hammerfest within the next 10 days. This dispatch was sent by express steamer from Adventfjorden [Advent Bay, Svalbard] and thence with a German tourist ship to Digermulen. (Bergens Tidende 18 July 1906)

It was important to Wellman to broadcast news of the expedition swiftly, and the expedition built its own telegraph station in Hammerfest in order to be able to transmit dispatches directly from the North Pole via Danskøya to Hammerfest, and thence to the rest of the world. In Nordkap we are able to follow the problems encountered during the building of the telegraph station (15 June) and disagreements about the cost of the upkeep of the station (31 August). Wellman's telegraph system was a complex affair: To facilitate the sending of dispatches to the outside world, Wellman had three independent wireless stations constructed. Station No. 1 was built at Hammerfest in Norway and connected there to the station at Tromsø and its connection with the Atlantic cable. Station No. 2 was inside the Chicago Record-Herald House (also known as the Wellman house ...), six hundred miles north of Hammerfest. Station No. 3 was on board the dirigible itself; its wireless, the journalist 
envisioned, would broadcast the news from nearly seven hundred miles north of his base camp that the airship had reached the Pole. Should he reach the Pole, Wellman was taking no chances that his story would be scooped. (Capelotti 1999: 68)

In a dispatch published a few days later we see that Wellman's telegraph system worked. Bergens Tidende started their short article in the following way: "The Wellman Expedition. London. From Danskøya on the 20th of this month, in a wireless telegram to the Reuters office via Hammerfest..." (Bergens Tidende 23 July). In his book, Capelotti illustrates this with a facsimile of a cutting from The Chicago Record-Herald from 24 July 1906, featuring a telegram to President Roosevelt from Hammerfest dated 21 July. It read: "Roosevelt, Washington. Greetings, best wishes by first wireless message ever sent from arctic regions. WELLMAN" (Capelotti 1999: 71).

At the turn of the month between June and July, while Wellman was staying in Tromsø before heading north towards Spitsbergen, Tromsøposten ran two lengthy articles as well as a number of smaller announcements about him. The first long article (23 June) was reprinted from Aftenposten, the national newspaper, and was a report from Paris on Wellman's presentation of his dirigible at the workshops of Louis Godard, the pioneering French balloonist. The author, Carl Muusmann, describes Wellman as a "Stanley-type with a mighty moustache over the slightly brutal mouth and a clean-shaven chin. He wears a jacket and a sailor's cap, making him look very much like a sea captain". The article, which describes the airship America's dimensions and properties, is rounded off with a few financial questions posed to Wellman:

-And how much will the expedition cost?

-At least 1,250,000 francs.

After receiving this intelligence one stares once again in awe at all the strange equipment until it is time to bid Wellman farewell and bon voyage.

-And you believe you will reach the goal?

-I hope so, replies the American dryly. If we don't

succeed this time, we will try again.

This is how you may allow yourself to talk when you

have millions at your disposal. (Muusmann 1906, in

Tromsøposten 23 June)

The next article, a week later (30 June), describes the ship and reports on Wellman's plans and assumptions.

The expedition attracted tourists and other interested parties to Spitsbergen. For example, the journalist Otto von Gottberg, from the German newspaper Berlin Lokal Anzeiger, established his own camp at Virgohamna to follow the efforts of his American colleague-most likely in order to prove that the whole thing was a publicity stunt for The Chicago Record-Herald. (Several Norwegian newspapers quoted the Berlin newspaper.) The Norwegian photographer Anders Beer Wilse was also there, as one of the passengers aboard the Neptun, a tourist ship. From 18 to 20 August 1906 he took a whole series of photographs of the construction work at Wellman's camp. This series includes the unfinished balloon shed, building material, the car, a sledge, the motor and propeller of the airship, the monument to Andrée and the Frithjof, the Norwegian ship that Wellman used that summer. Wilse returned to Danskøya in 1907 and again in 1909 to document more of Wellman's progress. All of these photographs are found on the website of the National Library of Norway (http:// www.nb.no/gallerinor/fotografer/ab_wilse.php).

Fridtjof Nansen, the world-renowned polar explorer, scientist and humanitarian, was critical of Wellman. Nansen visited Spitsbergen in 1912 and landed at Virgohamna. He reflected that:

It was here, then, that the American Wellman spent several years inflating his expedition and his airship. A perfectly strange undertaking of its kind. To all experts in the field it was clear from the very start that his plans for the North Pole were exceptionally useless; but all the same, it received full backing from an American newspaper, which undertook to bear all the costs, and these were considerable. Wellman had seen what sort of sensation Andrée's unfortunate airship journey had aroused; this could be utilized on a grander scale.

In the course of several years (from 1906 to 1909), the newspapers of the world were thus filled with constant dispatches about every step of this strange expedition's preparations, about all the glorious feats it was to accomplish and about all the most modern inventions that were to be used. (Nansen 1920: 141; this and other quotations from Nansen's book have been translated by the authors)

Nansen's description of Wellman's ineptitude clearly showed his distaste for such hyped-up expeditions led by men merely seeking honour and fame. The descriptions of Wellman's four attempts to reach the pole are sarcastic reading; he portrays an explorer who had no business being in the Arctic. He writes of the tourist ships that "each summer brought hundreds of tourists to Spitsbergen, where Wellman was the star attraction" (Nansen 1920: 142). He was critical of Wellman's use of the world's newspapers. In the aftermath of each failed attempt, wrote Nansen, Wellman travelled "back to Europe to tell of his great achievements and to build a new airship" (Nansen 1920: 143). Nansen was of the opinion that a polar expedition should be a combination of science, adventure and the peak of physical exertion. A polar expedition was no show. "The Greatest Show in the Arctic" was exactly what Wellman's expeditions werethis is also the title of one of the chapters in Capelotti's book. Nansen characterizes Wellman as follows: 
A strange man who demonstrates how one may, with the help of the great art of advertising, keep the world's newspapers attention year after year without having one single thing of interest to report. It's simply a matter of knowing what sort of material the newspapers crave in order to satisfy the world's spiritual needsand in this area the man was truly great. (Nansen 1920: 145)

Nansen recognized Wellman's skill at selling his project and maintaining the public interest and gave him credit for that. Wellman probably deserves greater space in the history of the media than in the history of polar exploration. In their book on the history of the media in Norway, Bastiansen \& Dahl (2005) write about the telegraph, the press and film in their chapter about the great technological revolution between 1850 and 1920 . Wellman was an Arctic pioneer in all of these areas:

The newspapers' telegrams documented the telegraph's speed to the public. It was as if they said to the readers: if it is urgent, then use the telegraph. At the same time the telegraph had its influence on the press. The telegrams reinforced the newspaper's role as a news medium; the transition from opinion-press to newspress was facilitated by the telegraph. (Bastiansen $\delta$ Dahl 2005: 213; translated by the authors)

According to Capelotti, who has dug through the newspapers from the time Wellman announced his plans for a North Pole expedition,

Within three days of Wellman's announcement of the polar airship expedition in late 1905, the plan was greeted by newspapers across the country and around the world by a combination of comment that ranged from interested optimism to tolerant bemusement to open ridicule. (Capelotti 1999: 117)

The Chicago Record-Herald's wealthy owner, Victor Lawson, sponsored Wellman's trip knowing that such material sold newspapers. Among the newspaper stories Capelotti tracked down, a comment printed in The Cleveland Plain Dealer declared that, "Whether Walter Wellman reaches the North Pole or not there will be a lot of interesting news connected with the daring venture, and the newspaper that backs him is well aware of this fact" (5 January 1906; quoted in Capelotti 1999: 119). Many newspapers agreed on the fact that this was a great media event:

Correspondent Walter Wellman's assignment to build an airship, proceed to the North Pole and report by wireless is the biggest one yet. It even outdoes Mr. Bennett's memorable order to Mr. Stanley to go to Africa and find Livingston. (Boston Herald 3 January 1906, quoted in Capelotti 1999: 119)

In addition to attracting journalists and tourists and filling the newspapers with Arctic material, Wellman also managed to awaken the interest of the infant film busi- ness. According to Capelotti, Wellman's "biographer", E. B. Baldwin's diary of Wellman's expedition to Franz Josef Land in 1898-99 mentions that a "cinematograph" was used to record their arrival in the Arctic (Capelotti pers. comm. 2006). Wellman's brother Arthur reportedly filmed Wellman's dirigible taking off at Svalbard in 1909, during a later attempt to reach the North Pole (Capelotti 1999, pers. comm. 2006). Although Wellman seems to have been aware of film's potential, there is no evidence that Wellman himself brought along a film camera to document his progress towards the North Pole before the 1909 attempt. This is probably because Wellman had made a deal with the Warwick Trading Company, giving them the rights to film the 1906 expedition.

A film with the title The Wellman Polar Expedition is described in the second volume of Rachel Low's History of British film (1997). According to Low, the most important of all the expedition films "was that of the Scott Antarctic expedition, which may in fact be described as one of the really great achievements, if not the greatest, of British cinematography during this unhappy period" (Low 1997: 155). She continues:

It is not the first example of polar cinematography. The Warwick Trading Company had sent an operator (J.H. Avery) with the Wellman Expedition, which tried to reach the North Pole by airship and motor sleigh in the summer of 1906, and had received $6000 \mathrm{ft}$ of film by the autumn which, however, apparently proved unsatisfactory and were heard of no more. (Low 1997: 155)

One of the many short-lived trade magazines from the infancy of films, Cinematography and Bioscope Magazine (1906-07) was published by the Warwick Trading Company. The magazine made much of the coming film about Wellman's polar journey. In addition to some smaller notices about trials of the motor sleigh Wellman had planned to bring along in the airship, the magazine ran two major articles about the planned film. The first article, in the May 1906 issue, was a combination of selfaggrandisement by the film company and a description of the agreement with Wellman to participate in the expedition. The anonymously authored article, entitled "ENTERPRISE. The North Pole this time", boasts that no contemporaneous film companies had accomplished more "daring and enterprising exploits with the Bioscope Camera than Warwick" and that "It is an indisputable fact that we have more negatives of Natural Subjects than any THREE other cinematographs put together" (1906: 33). After listing a number of grand journeys to Canada, Sudan, India and other countries, the article declares, "We hope to eclipse even this wonderful record" (1906: 33). It went on:

By courtesy of Walter Wellman, Esq. of The Wellman Chicago Record-Herald Polar Expedition, accommoda- 
tion has been made to allow one of our operators to accompany the expedition, to what we hope will be their destination, the North Pole. As many of our readers are aware, the participators in this scheme are hopeful of carrying out their project by means of a gigantic Air Ship, in conjunction with Motor Sleighs, etc. The building of the air house and gas works, the putting together of the air ship, the trials, the departure, and, we hope, their successful return, should make one of the most unique series of animated pictures ever yet "Bioscoped." (Cinematography and Bioscope Magazine, May 1906: 33)

Towards the end, the article cites a story in a newspaper called The Morning Leader, which gave an overview of the members of the expedition:

Mr. Wellman, who has been twice to the Arctic, is the leader, and is assisted by Major Hersey. The expedition includes six Americans, three Frenchmen, one Englishman (a cinematograph operator of the Warwick Trading Company), and a number of Norwegians. (Cinematography and Bioscope Magazine, May 1906: 35)

The rest of the article described Wellman's plans and equipment. In the next issue of the magazine, in June 1906, it reported on the departure of the Warwick Trading Company's cameraman northwards to cover the expedition:

Our operator, Mr. J. Roseman . . left London on May 25 th to join the remaining members of the expedition at Tromso [sic]. He had tons of baggage with him, which took three cabs to convey it to the station. About fifteen of our employees went to King's Cross to see him off; and as the train steamed out the station [sic], three rousing cheers were given, which nearly took the roof off. It was quite an exciting moment, and even our operator himself realised that he was commencing on one of the most perilous journeys of his life. On returning to the office, one of our men was successful in securing a prize-winning tram ticket. We cannot overlook this fact, as it seems an omen of success to our latest undertaking. (Cinematography and Bioscope

Magazine, June 1906: 59)

Note that Low (1997) gives the name of the Warwick cameraman as J.H. Avery, whereas the Cinematography and Bioscope Magazine piece says it was J. Roseman. Is this a mistake or did two Warwick cameramen travel to Norway and Svalbard to document Wellman's bid for the North Pole? We don't know. We do know that Warwick also had cameramen at the royal coronation in Trondheim-there were 18 in all-and the company's magazine advertises two films from the royal journey around the country: one documenting the journey along the coast from Molde to Trondheim, and one of the coronation itself. A search of the adverts for new films in the trade magazine reveals that the company visited Norway several times during the period in question: there was a film of the Holmenkollen skiing events in 1907, one of some military manoeuvres and one about the production of ice!

The foregoing excerpts from Cinematography and Bioscope Magazine give a good indication of the resources the Warwick Trading Company was willing to put into covering the polar expedition. But, as Low wrote, there are no traces of Warwick's Wellman film itself. However, in June the trade magazine advertised another film, entitled With the Wellman Polar Expedition, as being for sale:

With the Wellman Polar Expedition.

In our last issue we announced that facilities have been granted us to accompany the Wellman Polar Expedition, which is attempting to reach the Pole, by air-ship and motor sleighs. The film under review shows one of the latter, which has been christened by Mr. Walter Wellman, a "mechanical dog", being tested on the Norwegian ice fields by the inventor, Major Henry B. Hersey, one of the US Government. It is seen drawing three other sleighs, the first one being the one used by Nansen, the second one carrying petrol, and the third one a sleigh of the usual type. The front wheel is in the form of a drum which grips the ice, and the runners are absolutely flexible steel, which are built on an ankle joint, thus giving in any direction in going over uneven surfaces. The capabilities of this ingenious motor are well demonstrated as it passes on the screen. The next scene is extremely interesting and shows the motor hauling three logs of timber, which are equivalent to a load of 4,200 lbs. In the next view the motor is seen overcoming obstacles. The movement, as it runs over a mound of snow, is indeed very graceful and shows the advantages of the flexible runners already referred to. The motor also passes over a frozen sheet of water the surface of which has been melted by the sun. As it runs through the water the effect is very fine, and the reflections add considerably to the excellence of the picture. It then approaches in full view on the screen, an excellent portrait thereby being obtained of the inventor and driver. This is unquestionably a film that should be in every showman's list, for it is full of intense interest, and will be admired wherever it is shown. The length is 200 feet and the price $€ 5$. (Cinematography and Bioscope Magazine, June 1906: 47)

This detailed description does not jibe with what Low, quoted earlier, had to say. According to her, the footage6000 feet of film received by the autumn of 1906-taken by the Warwick cameraman, whoever he was, was "unsatisfactory" and was apparently not used (1997: 155). Perhaps only limited segments of the Warwick footage proved interesting and of good enough technical quality to be made into saleable short films, such as the 
one described above, featuring the Major's "mechanical dog". It is also possible that an accident befell the original footage, damaging much of it and thereby rendering it unusable. These are only guesses.

Footage of Wellman's polar expedition does survive in the British National Film and Television Archives: the 1906 film, The Wellman Polar Expedition-set out from Bergen to Spitzbergen. Records in the archives attribute the film to the Charles Urban Trading Company and the cameraman is named as Emile Louis Lauste, a Frenchman. This is the film of which we have received a copy.

According to the British Film Institute's online guide to British film history, the American Charles Urban (18671942) was an influential film producer and distributor in pre-war Britain. He worked for the Warwick Trading Company until forming the Charles Urban Trading Company in 1903, where he pursued his interest in actuality, travel and science films, as well as producing fiction films. The Wellman Polar Expedition is listed in the British Film Institute's online guide among several hundred films that Urban's company produced between 1903 and 1923. Apart from this we have only one other contemporaneous reference to the film-an entry in The Kinematograph and Lantern Weekly from 30 May 1907 (Fig. 5), in which the Urban Trading Company advertises a film of $500 \mathrm{ft}$ made in the summer of 1906 about the Wellman expedition entitled The Wellman Polar Expedition. A Visit to Danes Island. The advertisement proudly announces that the film is "the only animated picture record of the first attempt, in July of last year". In the advertisement, a number of the subjects are described:

In the Arctic Regions: Hunting Party leaving for the Coast. Panoramas of Bergen, Spitzbergen and the Fiords.-Life in a Lapland Village.-_Return from the Hunt.- The Steamer aground on a rock.- - Visit to Danes Island.-Arrival at Mr. Wellman's Headquarters.-Landing of the Scientific Party.-Panorama of the Camp.-Group of Lap Guides.-Mr. Wellman leaving Danes Island etc., etc.

This description corresponds well to the film in the British National Film and Television Archives. The title of the 1906 film has been changed and a few feet have been added: the British National Film and Television Archives film is $470 \mathrm{ft}$ long, whereas the The Kinematograph and

Figure 2 Stills from the film. From top to bottom: Saami people, northern Norway; the spoils of a reindeer hunt, northern Norway; the German coastal steamer, Friesland, which visited Virgohamna around 20 July 1906, at about the same time as the Ille de France; Wellman and a crowd of tourists at Virgohamna in 1906. In the background of the last frame is Pike's house, built by the British sportsman Arnold Pike in the early 1890 s and used by the Wellman expeditions of 1894 and 1906-09 and the Andrée expeditions of 1896-97.

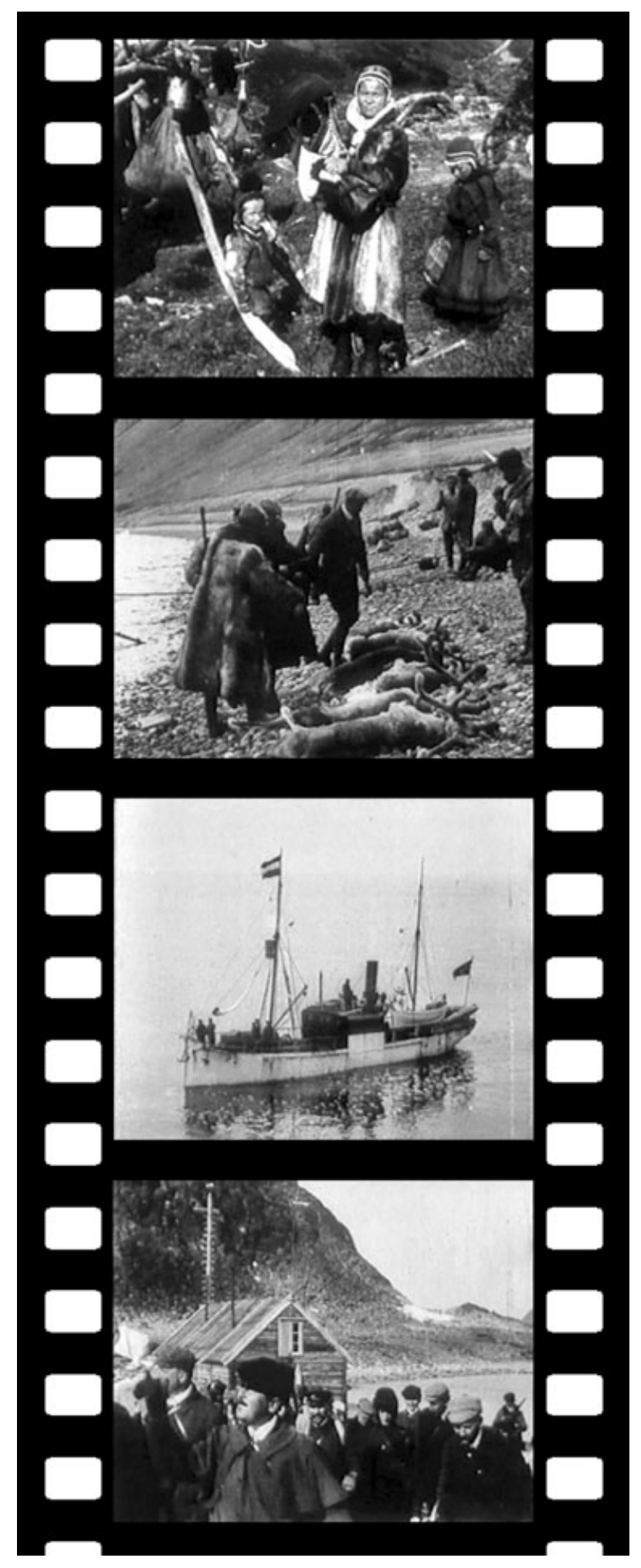




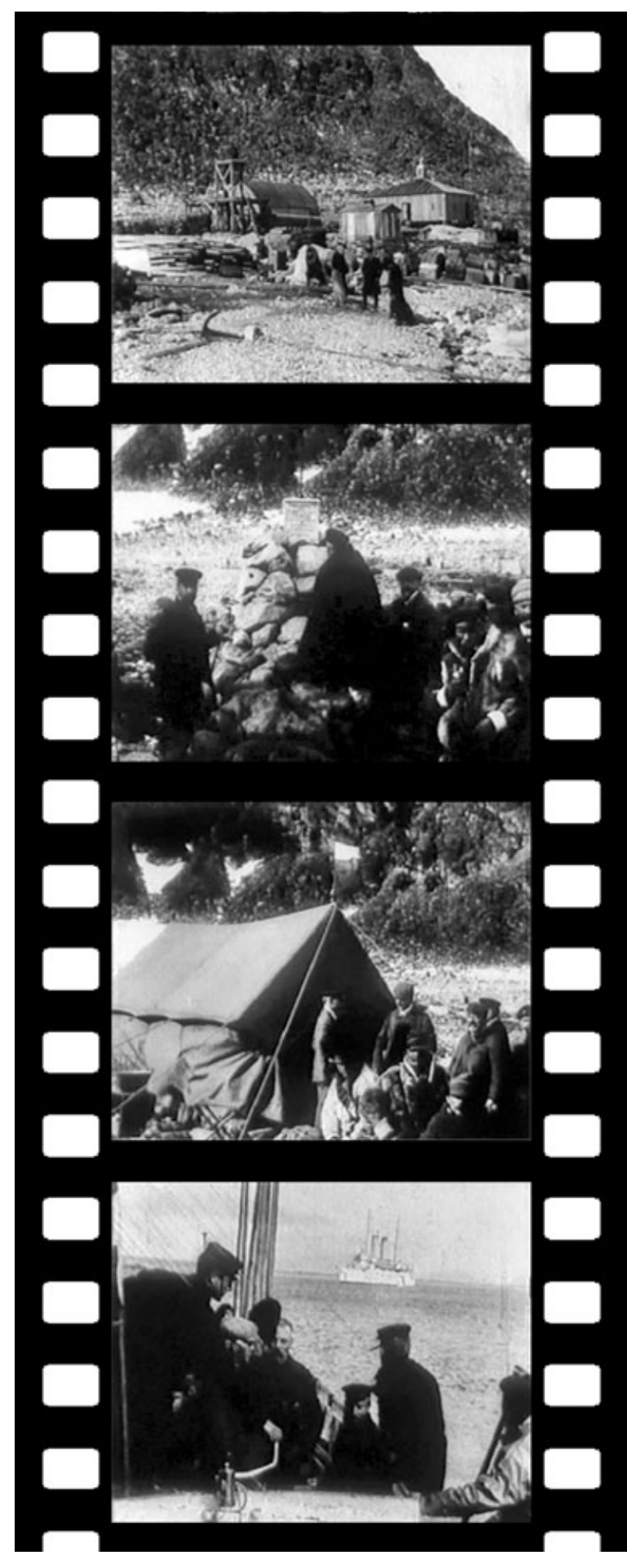

Lantern Weekly advertises the film as being $500 \mathrm{ft}$ in length. The 1906 film is eight minutes long and lacks intertitles, which was not unusual in films of this era (Thompson \& Bordwell 2003). The scenes do not appear to have been edited entirely chronologically: there are sudden jumps from mainland Norway to Spitsbergen and back again to the continent.

The 1906 film opens with tourists in horse-drawn carriages on their way to the top-we think-of Ulriken, one of the mountaintops around Bergen that was a tourist attraction at the time. Next we see the harbour area of Bergen, including the small Laksevåg ferries and the part of town known as Nordnes. After that we move rapidly up the Norwegian coast with panoramic shots of Sunnmøre and Hjørungfjorden taken from a boat. Suddenly, we find ourselves on Spitsbergen, the largest island of the Svalbard archipelago, with its snowy mountains reaching right down into the sea.

The next scene is a longer composition in which we see tourists in ships' rowboats being set ashore on a desolate beach. There are no snowy mountains here: in the background are barren coastal cliffs. This is obviously a hunting expedition in mainland Norway: a good number of the party carry rifles. There is even a horse in one of the boats. The film then cuts to an indigenous dwelling with Saami families posing for the camera (Fig. 2), holding up reindeer antlers, ad with children in traditional garb and so on. Then the film cuts back to the hunting party, which is returning to the boats with their quarry-half a dozen reindeer (Fig. 2).

Then we are back on Spitsbergen and in Kongsfjorden (King's Bay). We see a boat moving through drift ice in towards the bay of Virgohamna, on the small island of Danskøya off north-westernmost Spitsbergen. We see more ships in the vicinity of the harbour-these are the German Friesland (Fig. 2), according to the synopsis on the British Film Institute's website, and the Norwegian Frithjof (Capelotti, pers. comm. 2006).

There then follows a number of scenes from the camp in Virgohamna. We see tourists being set ashore, 


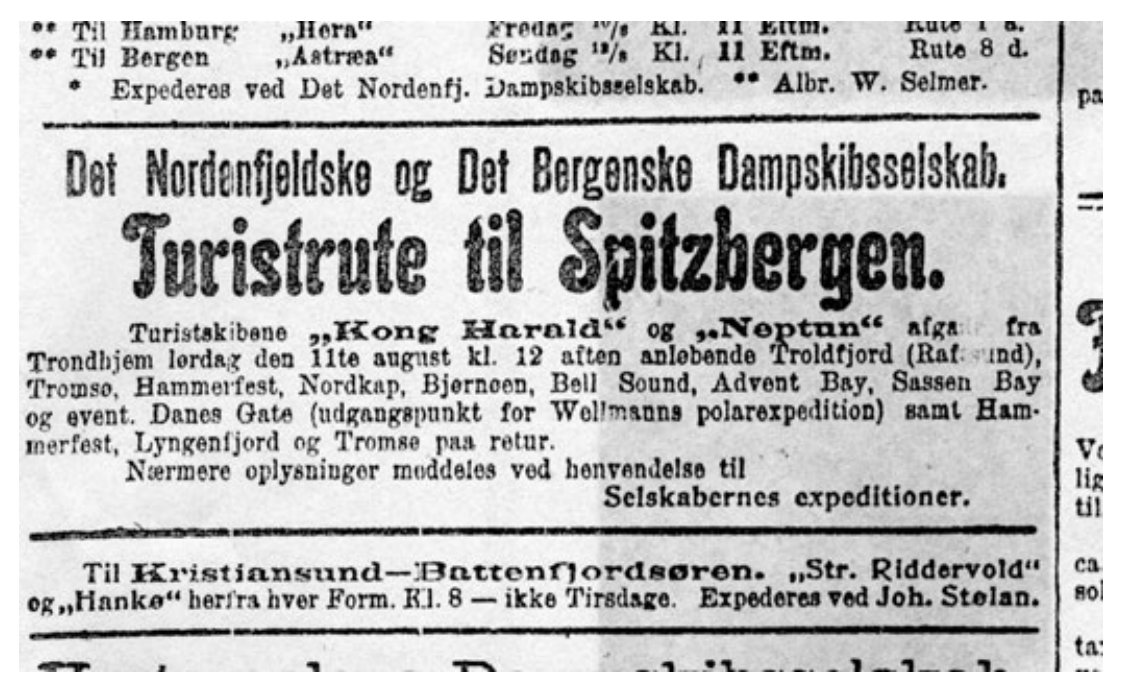

Figure 4 An advertisement for a tourist cruise in the newspaper Trondhjems Adresseavis, 10 August 1906. Note the mention of "Danes Gate (starting point for Wellman's polar expedition)".

Wellman onshore (Fig. 2), a long pan showing the Wellman house with its American flag (Fig. 3), the camp of the German journalist, Otto von Gottberg, the memorial stone for Andrée's balloon expedition, and scaffolding for the balloon hangar. The film cuts to close-ups of the members of the expedition, Wellman taking notes at Andrée's memorial (Fig. 3) and Gottberg conversing with tourists (Fig. 3), before the film ends with close-ups of Wellman as he is rowed out to one of the tourist ships (Fig. 3) while he smiles and doffs his cap to the cinematographer.

Emile Lauste, the camera operator on this film, was an experienced cinematographer. According to the records of the British Film Institute, he worked on 11 other films, mostly documentaries, between 1898 and 1922. With one exception (a German film), the films were produced by British production companies, and two of them were for the Charles Urban Company: the Wellman film and a film of the Zambezi River and Victoria Falls. Lauste may well have worked on many more films than those in the British Film Institute's records. Yet there is nothing to indicate that the Charles Urban Company's Wellman film was made in close cooperation with the expedition itself. It lacks the intimacy and detail that one would expect from a film that enjoyed the kind of filming rights that the Warwick Trading Company boasted about in its magazine. We conclude that this film in fact records a tourist trip up the coast of Norway and on to Virgohamna. This explains why the pictures appear to be taken from a respectable distance: the photographer, although working to professional standards, was working from the vantage point of a tourist.
On 28 August, Tromsøposten printed a lengthy telegram about the journeys of the Norwegian tourist ships Neptun and Kong Harald to Spitsbergen (Fig. 4). The ships sailed to the margin where open sea met pack ice at $81^{\circ} \mathrm{N}$; passengers viewed whale carcasses about to be processed at Bellsund and visited the coal mines at Adventfjorden. A hunting trip took place in Sassenfjorden. The climax of the trip was a 10-hour stop in Virgohamna:

Wellman and the other participants of the expedition gave us a charming reception. We were afforded the opportunity to inspect everything. The colossal balloon-shed, whose skeleton is nearly fully erected, as well as machines and equipment, the site and remains of Andrée's balloon-shed, Mr. Pike's house ... Wellman and Major Hersey, the expedition's American participants, were invited to dinner onboard the Kong Harald. Some especially interested passengers from the Neptun were also invited . . Passengers immediately seized glasses, cups and spoons used by Wellman while he was onboard and then demanded certificates authenticating their spoils. After dinner, Wellman visited the Neptun. The passengers of both ships gave large ovations upon his de-embarkation. The general impression from conversations with Wellman was that an ascent this year, while not out of the question, all the same was considered unlikely, due to delays in the work caused by inclement weather conditions. It is most likely that the expedition will leave towards the end of September, leaving behind them a number of engineers and workers to take care of everything until next summer. Photographers and amateurs from the ranks of the passengers of both vessels take a large 


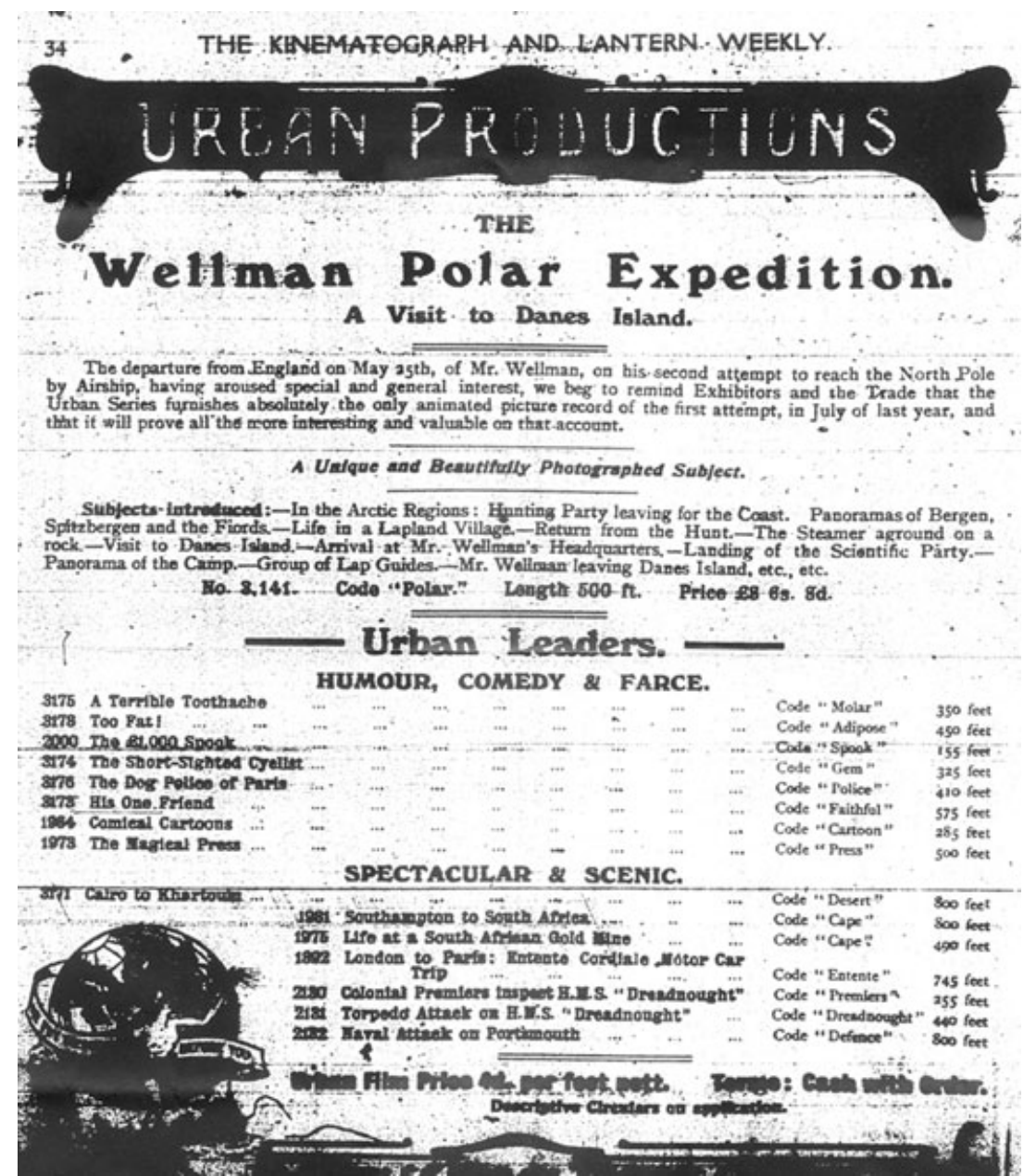

Figure 5 An advertisement in The Kinematograph and Lantern Weekly, 30 May 1907. amount of photographs. Favourable group photographs were taken of the passengers of both ships as well as Andrée's stone with all nations' flags. 8 degrees below zero at the edge of the pack ice. Overwhelming impression. (Tromsøposten 28 August 1906)

The Neptun and the Kong Harald were only two of the numerous ships that stopped in at Virgohamna that summer so that tourists could gawk at the Wellman show, taking photographs and perhaps pocketing a souvenir. During the summer of 1906, tourist ships from Britain, Finland, France and Germany, as well as a dozen ships from Norway, arrived at the Wellman camp (Melding fra poststyrelsen 2007). Among the passengers of the French vessel, the SS Île de France, arriving 14 July, was Emile Lauste, the cameraman from the Charles Urban Trading Company.

We are left with unanswered questions. Why did Charles Urban make a film about the Wellman expedition, when the Warwick Trading Company had already made a special arrangement with Wellman, and what was the the fate of the much-touted Warwick footage? According to McKernan (1999), Urban was engaged in disputes with his former employer for several years after he left the Warwick Trading Company in 1903. We can therefore speculate that Urban was simply motivated to make and distribute moving pictures of Wellman before his rival did.

The next summer there weren't quite as many tourist ships at Virgohamna. Although he tried again, Wellman never made it to the North Pole and there is nothing to suggest that either Charles Urban or the Warwick Trading Company sent anyone to Svalbard after 1906.

\section{Acknowledgements}

We are grateful to Prof. Peter Capelotti and friends and colleagues from the British Silent Cinema Festival, especially Bryony Dixon, of the British Film Institute, and film researchers Jude Cowan and Tony Fletcher. 


\section{References}

Anonymous Cinematography and Bioscope Magazine, May 1906: 33 , p. 33.

Bastiansen H.G. \& Dahl H.F. 2005. Norsk mediehistorie. (Norwegian media history.) Oslo: Universitetsforlaget.

Bergens Tidende 1906. Wellmanekspedition. (The Wellman Expedition) 18 July, p. 2.

Bergens Tidende 1906. Hvem er Walter Wellman? (Who is Walter Wellman?) 20 July, p. 1.

British Film Institute. Urban, Charles (1872-1942). In Screenonline: the definitive guide to Britain's film and TV history. Accessed on 21 January 2007 at http://www. screenonline.org.uk/people/id/514893/.

British Film Institute. Online Film and TV Database. Pages http://ftvdb.bfi.org.uk/sift/title/69637?view=synopsis and http://ftvdb.bfi.org.uk/sift/individual/81362 accessed on 21 January 2007.

Capelotti P.J. 1999. By airship to the North Pole. An archaeology of human exploration. New Brunswick: Rutgers University Press.

Capelotti P.J., Van Dyk H. \& Caillez J.-C. 2007. Strange interlude at Virgohamna, Danskøya, Svalbard, 1906: the merkelig mann, the engineer and the spy. Polar Research 26, 64-75.

Cinematography and Bioscope Magazine 1906. Enterprise. The North Pole this time. May, p. 33.

Cinematography and Bioscope Magazine 1906. With the Wellman Polar Expedition. June, p. 47.

Cinematography and Bioscope Magazine 1906. The Wellman Polar Expedition. Our operator leaves London. June. Pp. 57-59.
Drivenes E.-A. \& Jølle H.D. 2004. Norsk polarhistorieekspedisjonene. (Norwegian polar history - the expeditions.) Oslo: Gyldendal.

Kinematograph and Lantern Weekly 1907. Advertisement for Urban Production's film. 30 May, p. 34.

Low R. 1997. History of the British film 1906-1914. Vol 2. London: Routledge.

McKernan L. 1999. A Yank in Britain: the lost memoirs of Charles Urban, film pioneer. Hastings, East Sussex: The Projection Box.

Melding fra poststyrelsen om oppretting og drift av "postaabneri" i Advent Bay paa Spitzbergen. (Announcement from the postal service about the establishment of "postaabneri" in Advent Bay, Spitsbergen.) Accessed on 18 January 2007 at http://home.online.no/ polar-ps/ adventbay.html.

Nansen F. 1920. En ferd til Spitsbergen. (A journey to Spitsbergen.) Kristiania (Oslo): Jacob Dybwad's Publishing House.

Thompson K. \& Bordwell D. 2003. Film history: an introduction. Boston: McGraw-Hill.

Tromsøposten 1906. Om Spitsbergenturene med "Neptun" og "Kong Harald". (On the journeys to Spitsbergen with the Neptun and the Kong Harald.) 28 August, p. 2.

Tromsøposten 1906. Den styrbare. I det parisiske ballonverksted. (The dirigible. At the Parisian airship builder's workshop.) 23 June, p. 1.

Trondhjems Adresseavis 1906. 10 August. 